\title{
Вплив засобів фізичної терапії на якість ходьби та показники електроміографії у студентів 17-19 років з плоскостопістю і порушеннями постави
}

\author{
УдК 615.825-052:616.8-009.18-057.87:616.7

\section{С. П. Наконечна, О. В. Баскевич}

Прикарпатський національний університет імені Василя Стефаника, Ївано-Франківськ, Україна

\begin{abstract}
Анотація. Робота присвячена розгляду біометричних параметрів ходьби студентів 17-19 років зі зниженням висоти склепіння стопи за даними системи SIGMA XL та ознаками функціонального сколіозу. Розглянуто такі часові параметри ходьби, як тривалість одного циклу кроку, одиночної опори, середня нормалізована швидкість. Проведено аналіз інтегрованого показника якості ходьби FAP. Мета. Оцінити динаміку та особливості часових параметрів ходьби до та після впровадження авторської програми корекції плоскостопості і функціональних порушень постави у студентів 17-19 років. Методи. Проаналізовано параметри ходьби 120 студентів з гіпо- гіпертонусом м'язів, які входять до складу різних міофасціальних ланцюгів. Студенти були розподілені на дві групи: основну (ОГ) та контрольну (КГ) по 60 чол. у кожній. Студенти ОГ займались за авторською програмою, яка передбачала застосування засобів фізичної терапії, передбачених методикою ї. Д. Ловейко [7], в модифікації О. В. Пешкової зі співавт. [12]. Крім цього, додатково проводили заняття модифікованими видами спорту у воді (поло, баскетбол, волейбол, імпровізовані ігри тощо) - температура води $25^{\circ} \mathrm{C}$, глибина басейну до 1,2 м. Студенти КГ займалися тільки за програмою ї. Д. Ловейко. Обстеження проводили на початку дослідження і через 12 і 24 міс. після застосування відповідних програм фізичної терапії. Результати. За результатами проведенного статистичного дослідження було виявлено деякі закономірності для студентів, у яких плантографічним методом визначалися ознаки плоскостопості і функціонального сколіозу (КГ) та для студентів, у яких постава залишалася без зміни (ОГ). До лікування студенти незалежно від групи дослідження за параметрами ходьби були однаковими, тобто у них простежувалися всі ознаки спотворення ходьби внаслідок плоскостопості. Через два роки після впровадження обох програм параметри ходьби відновлювалися, хоча їх нормалізація за програмою для КГ не досягала середньостатистичної референтної норми. Після лікування за авторською програмою спостерігалося значне покращення параметрів ходьби у студентів ОГ - практично відновлювалася симетрія ходьби. Висновки. Зменшення тонусу і дисбаланс м'язів гомілки і спини є об'єктивною причиною втрати навичок якісної ходьби, що студенти показували до впровадження авторської програми. Тобто тривале несиметричне навантаження м'язів призводить до втрати оптимальних показників ходьби, зменшення опорної спроможності стопи, що виражається збільшенням часу опори на стопу із порушенням склепінчастого апарату стопи і збільшенням тривалості кроку. Наслідком цих змін $є$ розвиток та поступове прогресування сколіотичної хвороби. Застосування у програмі фізичної терапії у студентів ОГ модифікованих ігрових видів фізичних вправ у воді сприяє підвищенню частотно-амплітудних характеристик м'язів окремих міофасціальних кінематичних ланцюгів, а зменшення дисбалансу між ними викликає покращення показників, що характеризують якість ходьби.
\end{abstract}

Ключові слова: плоскостопість; функціональні порушення постави; електроміографія. 
The influence of physical therapy measures on the walking quality and electromyography indices in students of 17-19 years with flat foot and posture disorders

\section{S. P. Nakonechna, O. V. Baskevych}

Vasyl Stefanyk Precarpathian National University, Ivano-Frankivsk, Ukraine

Abstract. The work is devoted to consideration of biometric parameters of walking of students aged 17-19 years with decreased height of a foot arch according to the SIGMA XL system and signs of functional scoliosis. The following walking parameters are considered: duration of one step cycle, single support, average normalized speed and analysis of the integrated FAP walking quality index. Objective. To evaluate the dynamics and features of time parameters of walking before and after the application of the physical therapy program in the remote observation period. Methods. The parameters of walking due to the hypohypertonic muscles that are part of the various myofascial chains are analyzed. In total, the data of 120 students were analyzed, who were divided into 2 groups: main (MG) and control (CG) of 60 people in every group. Students of MG were engaged in the author's program, which envisaged the use of the means of physical therapy provided by the method of I. D. Loveyko [7], in the modification of O.V. Peshkova et al [12]. In addition, there were classes in modified water sports (polo, basketball, volleyball, impromptu games, etc.) with a temperature of $25^{\circ} \mathrm{C}$ and pool depth of $1.2 \mathrm{~m}$. CG students were only engaged in the program of I.D. Loveyko (1982). The examination was performed at the beginning of the study and 12 and 24 months after the use of appropriate physical therapy programs. Results. According to the results of the statistical survey, some patterns were identified in students with flat foot signs and functional scoliosis (CG) revealed by plantographical method and in those whose posture unchanged (MG). Before treatment, students, regardless of the study group, had the same walking parameters, ie, they showed all signs of gait distortion due to flat foot. 2 years after the implementation of both programs walking parameters restored, although their normalization according to the program for CG did not reach the average statistical reference norm. After treatment under the author's program, there was a significant improvement in gait parameters in the students of MG - the symmetry of walking has almost restored. Conclusions. The decrease in tone and muscle imbalance of the lower leg and back is an objective cause of the loss of quality walking that students showed before the introduction of the author's program. That is, a long asymmetrical load of the muscles leads to the loss of optimal gait, a decrease in the foot capacity, which is expressed by the increase in the time of the foot support with the violation of the foot arch and increase of the step duration. The consequence of these changes is the development and gradual progression of scoliotic disease. The use of modified exercise types in water in the physical therapy program of students of MG helps to increase the frequency-amplitude characteristics of the muscles of individual myofascial kinematic chains, and to reduce the imbalance between them, which improves the indices characterizing the quality of walking.

Keywords: flatfoot; functional postural disorders; electromyography.

Постановка проблеми. Вертикальний спосіб пересування у просторі $\epsilon$ природною локомоцією, притаманною тільки людині $[5,13,17]$. Це відбувається в результаті складної координації у взаємодії скелетних м'язів, які входять до складу різних міофасціальних кінематичних ланцюгів (МФКЛ) $[9,15]$. Вони мають спіралеподібну структуру, відіграють роль «активної» частини ресорної фрункції опорно-рухового апарату і доповнюють «пасивні» амортизаційні властивості хребта і стопи, становлячи таким чином класичну «тріаду». Вона ефрективно поглинає силу пружної деформації, що закономірно виникає під час різноманітних рухів тіла людини [13].

Якщо через вади розвитку чи захворювання стопи і хребта якість ходьби ставиться під загрозу, то результатом може бути компенсаторне перенапруження МФКЛ у різних частинах тіла людини [4]. Коли воно триває довший час, то виникає виснаження функціональних резервів, що призводить до дисбалансу м'язового тонусу в різних частинах тіла, передусім, м'язів гомілки. Це, в свою чергу, веде до обмеження опорної здатності стопи і зниженя висоти склепінчастого апарату стопи (САС). У подальшому розвивається компенсаторний тонічний дисбаланс м'язів хребта і патологічне коло «стопа-хребет» починає активізувати дегенеративні зміни у всьому опорно-руховому апараті [6]. Такий підхід до розуміння механізмів розвитку комплексної патології стопи і хребта актуалізує наукові дослідження у осіб будь-якого віку. І не важливо, в якій стадії знаходиться захворювання. Якщо $€$ можливість його хоча би стабілізувати, то це вже буде мати певний прогрес у боротьбі з грізними ускладненнями у майбутньому $[7,8,11]$.

Аналіз наукової та спеціальної літератури показав, що фрізичні терапевти цією патологією в 
останній час займаються тільки у дітей 5-8 років, максимум до 10 років, або ці діти і підлітки стають клієнтами лікарів ортопедів-травматологів-вертебрологів [12, 18, 20]. Тому своєчасне виявлення причин і ступеня тяжкості порушень ходьби у людей з плоскостопістю та функціональними порушеннями постави $\epsilon$ одним із важливих завдань не тільки спеціалістів-медиків. Корекційно-відновне лікування необхідно проводити у взаємодії зі спеціалістами галузі фрізичної терапії у будь-якому віці [9].

Зв язок роботи 3 науковими програмами, планами, темами. Роботу виконано у ДВНЗ «Прикарпатський національний університет імені Василя Стефраника» відповідно до комплексної теми на 01.07.2017-30.07.2022 рр. «Використання немедикаментозних засобів і природних факторів для покращення фрізичного розвитку, функціональної і фрізичної підготовленості організму» (номер державної реєстрації 0117U001745). Роль автора полягала у розробці та експериментальному обгрунтуванні комплексної програми з фізичної терапії плоскостопості.

Мета дослідження - оцінити динаміку та особливості часових параметрів ходьби до та після впровадження авторської програми корекції плоскостопості і фрункціональних порушень постави у студентів 17-19 років.

Методи та організація дослідження. Були проаналізовані параметри ходьби 120 студентів, у яких до впровадження авторської програми виявлено різний ступінь тяжкості порушення САС і постави. Студентів було розподілено на дві групи: основну (ОГ) та контрольну (КГ) по 60 чол. у кожній. ОГ займалась за авторською програмою, яка передбачала застосування засобів фрізичної терапії, передбачених методикою І. Д. Ловейко [7], в модифрікації О. В. Пешкової і співавт. [12]. Крім цього, додатково проводили заняття модифікованими видами спорту у воді (поло, баскетбол, волейбол, імпровізовані ігри тощо) - температура води $25^{\circ} \mathrm{C}$, глибина басейну до 1,2 м. Такі заняття мають високий психоемоційний потенціал і їх охоче відвідують студенти протягом навчального року.

Студенти КГ займалися тільки за програмою І. Д. Ловейко [7]. Обстеження проводили тричі: до впровадження програми, через 12 і 24 міс.

Аналізували параметри ходьби на комп'ютерному комплексі «DIERS FAMUS» (Німеччина). Динамограма одного циклу кроку та одиночної опори показана на рисунку 1.

Показник FAP (Functional Ambulation Perfomance Score (FAPS, FAP Score)) - функціональна здатність пересування, $€$ одним 3 інтегральних показників якості ходьби, що базується

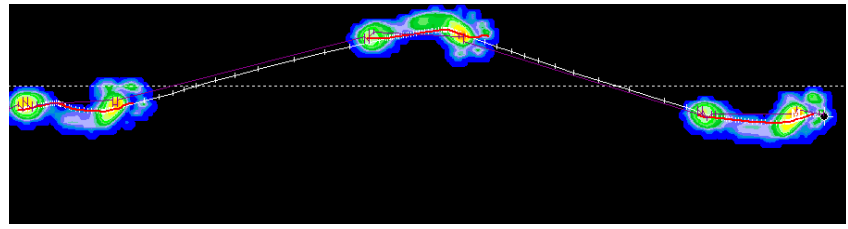

Рисунок 1 - Динамограма одного циклу кроку та одиночної опори в комплексі з кривими розподілу коливання послідовних центрів ваги (weigthline) і розподілу максимального тиску (maxline) у студента А., 18 р., 3 плоскостопістю і функціональним порушенням постави

на оцінці дев'яти параметрів і становить собою кількісну оцінку ходьби студентів, які отримані під час дослідження рівноваги [1]. FAP Score інтегровано в систему SIGMA XL силової доріжки та може вважатися золотим стандартом для аналізу якості ходьби $[4,16]$. Як рефрерентна норма були взяті дані Г. С. Московко [10].

Плантографічне дослідження доповнено електроміографічним дослідженням трьох МФКЛ м'язів гомілки та п'яти МФКЛ м'язів спини за допомогою апарату «Нейро-ЕМГ-Микро» (Росія).

Дані обстеження оброблені статистично. Були застосовані описова статистика (середнє та стандартне відхилення (M $\pm \mathrm{SD}))$, а також алгоритми порівняння: Т-тест для однієї вибірки для порівнянні параметрів із референтною нормою; парний Т-тест для порівняння параметрів правої-лівої стопи; Т-тест для незалежних вибірок для порівняння груп студентів. Аналіз проводили в пакеті «Statistica 11».

Результати дослідження. Аналіз індивідуальних медичних карт показав, що тільки 37,2 \% студентів не мають відхилень постави. При цьому 43,0 \% студентів хоча і не були хворі на сколіоз, проте мали різні відхилення від правильної постави (атонічна, асиметрична, сутула постава, кругла спина тощо) (рис. 2).

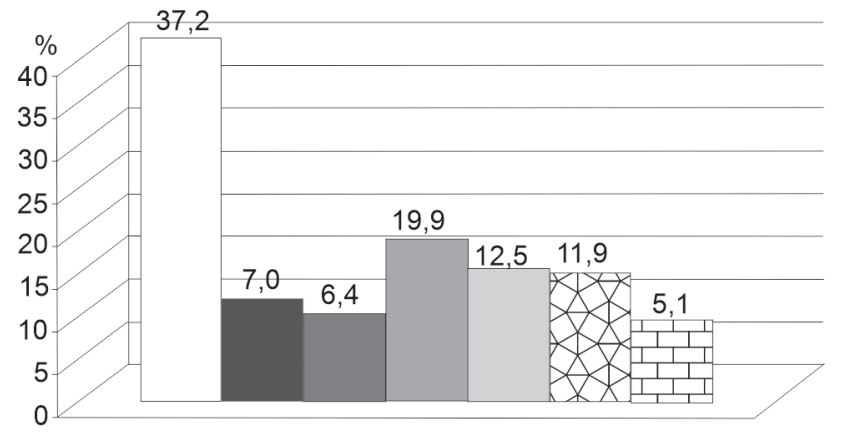

Рисунок 2 - Діаграма розподілу порушень постави за їх характером у студентів 17-19 років до впровадження засобів фрізичної терапії:

$\square$ - нормальна постава; $\square$ - атонічна постава; $\square-$ асиметрична постава; $\square-$ сутулість; $\square-$ кругло-ввігнута спина; $\square-$ сколіз 1 ст.; - сколіоз 2 ст. 
ТАБЛИЦЯ 1 - Розподіл студентів за характером порушення склепінчастого апарату стопи $(\mathrm{n}=120$, абс., \%)

\begin{tabular}{|l|c|c|}
\hline \multirow{2}{*}{\multicolumn{1}{|c|}{ Склепіння стопи }} & \multicolumn{2}{c|}{ Стопа } \\
\cline { 2 - 3 } & права & ліва \\
\hline Нормальне & $82(68,0)$ & $80(68,0)$ \\
\hline Високе (порожнисте) & $3(2,0)$ & $4(3,0)$ \\
\hline Сплощене & $9(7,0)$ & $10(8,0)$ \\
\hline Плоскостопість & $22(19,0)$ & $23(19,0)$ \\
\hline Плоско-вальгусне положення & $3,0(2)$ & $3,0(2)$ \\
\hline
\end{tabular}

Інші 17,0 \% студентів мають сколіоз І-ІІ ступеня. Слід зазначити, що у 60,4 \% випадків ці відхилення поєднуються з різними видами патології стопи (сплощенням склепіння, плосковальгусним положенням стопи, плоскостопістю різного ступеня), що відповідає даним наукової літератури [3, 19]. Аналіз розподілу студентів за характером порушення САС показав, що найбільша їх частина становить групу з функціональними порушеннями (табл. 1).

Результати ЕНМГ дослідження показали, що до фрізичної терапії у студентів у положенні лежачи спостерігається тонічна активність спокою без суттєвої асиметрії інтерференційної електроміограми справа/зліва (рис. 3, a).

При цьому показники максимальної амплітуди $\left(A_{\max }\right)$ становлять $30,2 \pm 3,83$ та 29,3 $\pm 1,97$ мкВ відповідно $(\mathrm{p}<0,05)$. У вертикальному положенні відмічається асиметрія міограм з більшою $\mathrm{A}_{\max }$ на стороні ввігнутої сколіотичної дуги, що становить в середньому 72,6 \pm 3,64 мкВ, і вірогідно $(p<0,05)$ відрізняється від показника ЕМГ на стороні випуклості (36,72 \pm 1,33 мкВ) (рис. 3, б). Цей ЕМГ-паттерн, на нашу думку, характеризує рефлекторну тонічну активність м'язів, які беруть

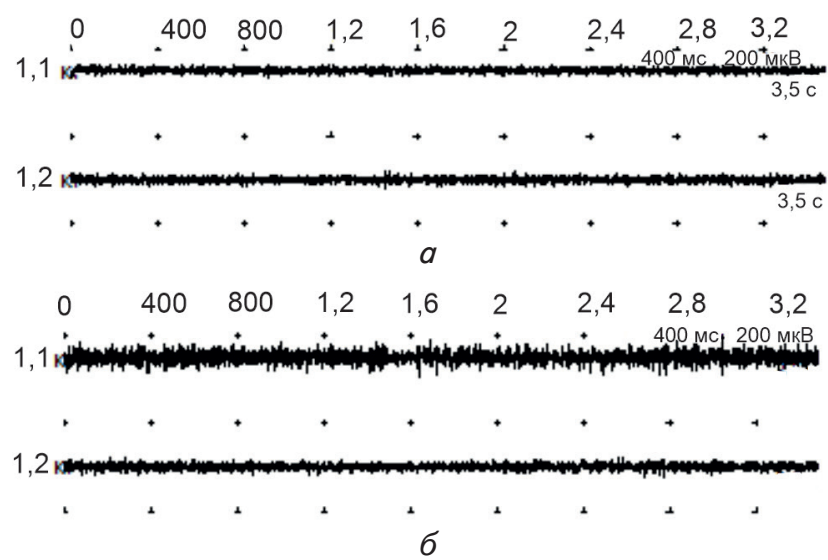

Рисунок 3 - Поверхнева ЕМГ пацієнта А., 18 р., до впровадження засобів фрізичної терапії правого $(1,1$ к.) та лівого (1,2 к.) м'яза-випрямляча хребта, міжребрового нерва, $\mathrm{T}_{9}-\mathrm{T}_{12}$ : $a-$ у положенні лежачи; б - у положенні стоячи
Спортивна медицина і фізична реабілітація, № 2, 2019

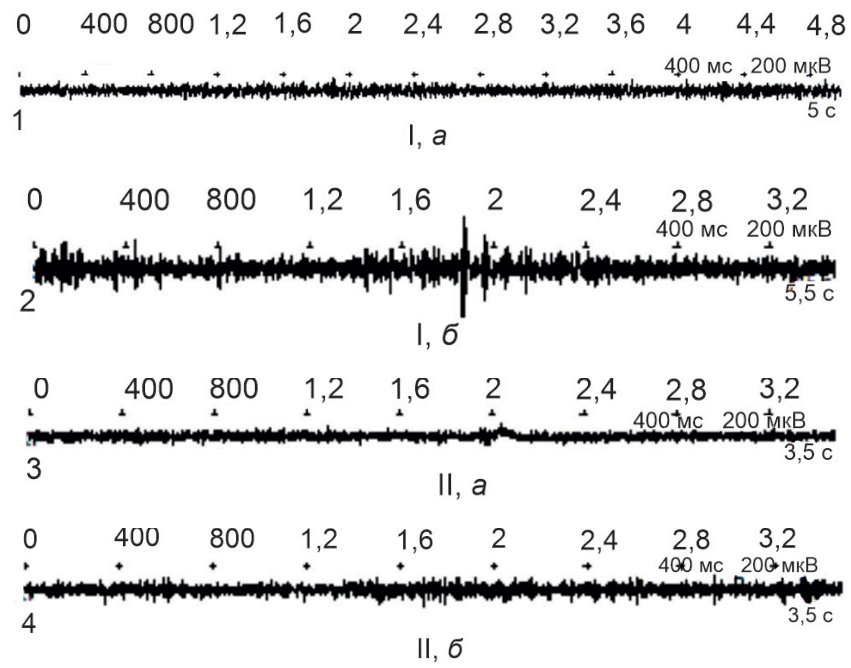

Рисунок 4 - Інтерференційна електроміограма м'язів, які входять до складу переднього (a) і заднього (б) міофасціальних кінематичних ланцюгів гомілки, що підтримують склепінчастий апарат стопи судента А., 18 р., з функціональним порушенням стопи (I) і студента П., 19 р., з плоскостопістю І ступеня (II):

1 - довгий м'яз-згинач пальця, великогомілковий нерв, $\mathrm{L}_{5}-\mathrm{S}_{1} ; 2$ довгий малогомілковий м'яз, поверхневий малогомілковий нерв $\mathrm{L}_{5}-\mathrm{S}_{1} ; 3-$ передній великогомілковий м'яз, глибокий малогомілковий нерв, $\mathrm{L}_{4}-\mathrm{S}_{1} ; 4-$ задній великогомілковий м'яз, великогомілковий нерв, $\mathrm{L}_{5}-\mathrm{S}_{2}$

участь у формуванні перехресного синдрому за рахунок утворення МФКЛ спини: поверхневого заднього, поверхневого і глибокого переднього, латерального та спірального [2].

Аналіз показників ЕМГ-дослідження у студентів 3 функцціональними порушеннями стопи показав, що вони мають найбільш виражений дисбаланс м'язового тонусу. Це виражається підвищеним тонусом латерального МФКЛ гомілки та зниженням тонусу м'язів стопи і заднього МФКЛ гомілки (рис. 4, б).

Характерним патерном порушення тонусу м'язів у студентів із плоскостопістю $€$ не тільки зниження загальної активності всіх м'язів стопи і гомілки, але й явно виражений дисбаланс активності між переднім і заднім МФКЛ (рис. 4, a, б).

Вивчення тривалості одного циклу кроку (GAIT Cycle Time) відображає не тільки характеристику довгого кроку, але й показує час опори, що витрачає пацієнт для переносу контрлатеральної кінцівки (див. рис. 1).

Під час вивчення даного параметра було виявлено деякі особливості ходьби студентів як до фрізичної терапії, так і після неї. Тобто тривалість циклу кроку у студентів значно різнилася порівняно зі значеннями норми при звичайній ходьбі і при ходьбі з метрономом, тобто при заданому темпі пересування. 


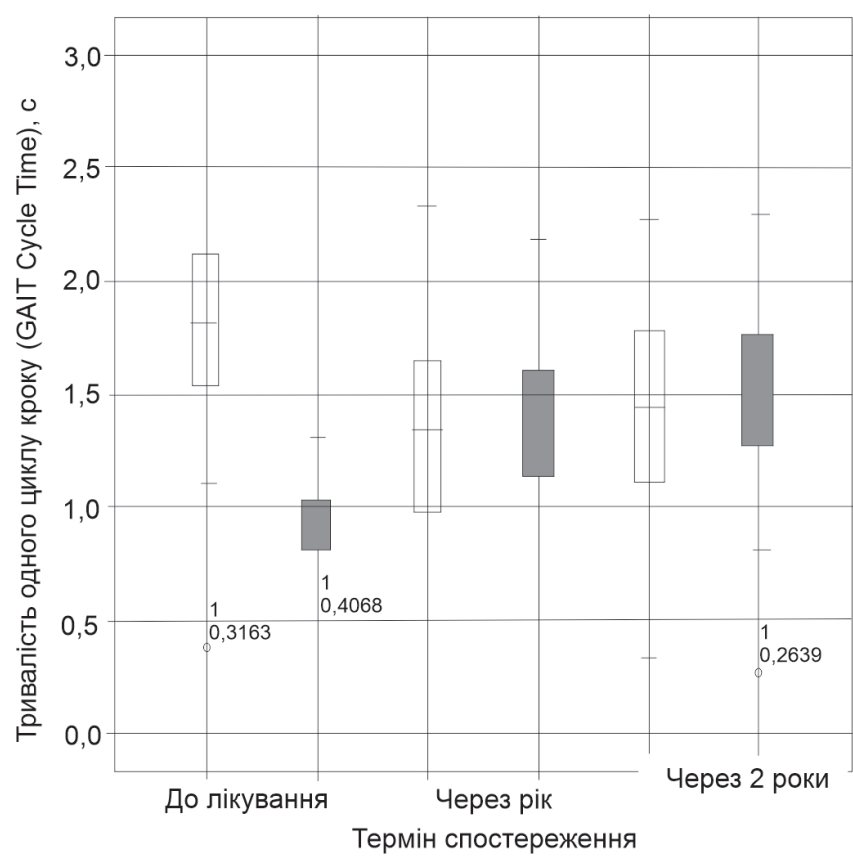

Рисунок 5 - Зміна упродовж спостереження параметра "тривалість одного циклу кроку» у студентів $(\mathrm{n}=55) 3$ плоскостопістю:

$\square$ - ліва кінцівка; $\square$ - права кінцівка

При нормі для звичайної ходьби 1,01 $\pm 0,01$ с вони пересувалися повільно, а при нормі цього параметра з метрономом 2,5 $\pm 0,1$ с - дуже повільно. Тобто ми не змогли визначити значення референтної норми, з якою треба порівнювати показники ходьби студентів. Порівняння проводили в різні періоди спостереження.

Під час роботи було виявлено, що до лікування тривалість циклу кінцівки у студентів тільки з плоскостопістю була у 1,9 раза меншою, ніж тривалість циклу кроку у студентів з комплексною патологією, і становила менше ніж 2,7 раза. У середньому різниця в тривалості циклу кроку хворої та здорової кінцівок у таких студентів становила 1 c, що має статистичну різницю $(p=0,872)$.

Через 12 міс. після впровадження авторської програми ми спостерігали практично повне вирівнювання тривалості кроків у студентів, в яких виявлено тільки порушення САС, і у студентів з комплексною патологією. Середні значення тривалості циклу кроків правої-лівої кінцівок дещо відрізнялися і становили відповідно 1,38 \pm 0,24 та 1,36 $\pm 0,42 \mathrm{c}(p=0,336)$.

Через 24 міс. середні значення тривалості циклу кроків правої-лівої кінцівок студентів становили відповідно 1,25 $\pm 0,07$ і 1,26 $\pm 0,04$ с $(p=0,126)$. Динаміка тривалості одного циклу студентів продемонстрована на рисунку 5 .

Одиночна опора (Single Support) як параметр ходьби оцінює спроможність стопи нести навантаження, вимірюється в секундах та оцінюється у відсотках до тривалості часу кроку відповідної кінцівки. Цей параметр взаємодіє з попереднім параметром «тривалість одного циклу кроку», тобто чим більше тривалість кроку однієї ноги, тим більше час опори на стопу другої кінцівки, і навпаки, зменшення тривалості переносу однієї кінцівки зменшує і час опори на стопу протилежної кінцівки (рис. 6).

За даними статистичного аналізу було визначено, що до лікування тривалість одиночної опори правої-лівої кінцівок у студентів майже не відрізнялась, але перевищувала показники норми майже в 3 рази. На цей період спостереження різниця параметра одиночного опору у всіх студентів була статистично значущою $(p=0,001)$. На цей період спостереження не було виявлено статистичної різниці між студентами ОГ $(p=0,314)$ i КГ $(p=0,321)$ за означеним параметром.

Через рік після впровадження авторської програми параметр «одиночна опора» для обох кінцівок зменшився $(p=0,340)$ і статистично значущо відрізнявся $(p=0,112)$ від показників до лікування.

Через два роки після впровадження авторської програми відмічалося зменшення тривалості одиночної опори, що має статистичну різницю порівняно з попереднім терміном спостереження $(p<0,01)$.

Середня нормалізована швидкість (Mean Normalized Velocity) $\epsilon$ найбільш сприятливою, ніж пряме визначення швидкості пересування. Взагалі швидкість пересування $\epsilon$ індивідуальним параметром, і для кожної людини показник «швидко-повільно» $\epsilon$ неоднозначним та

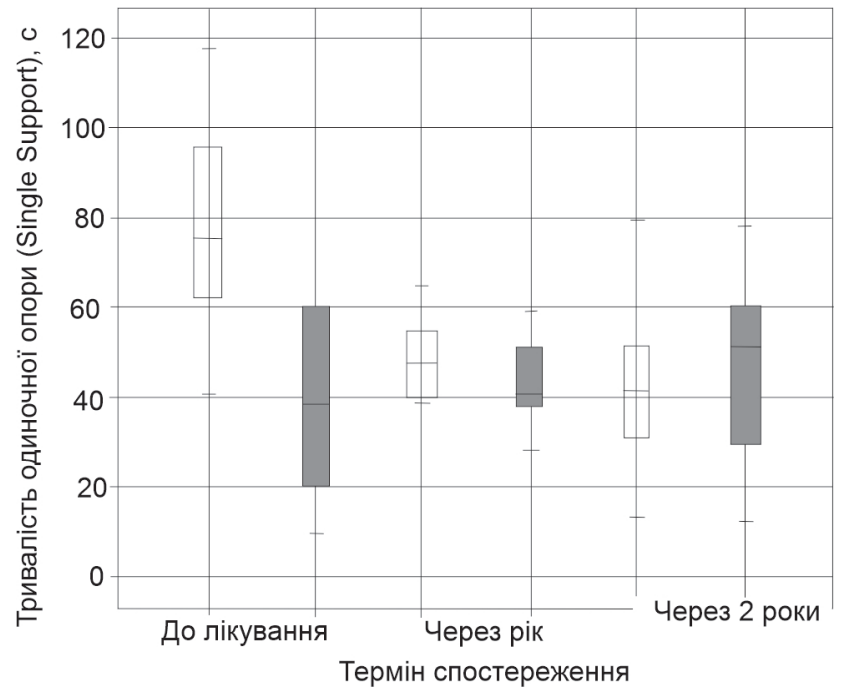

Рисунок 6 - Зміна упродовж спостереження параметра «одиночна опора» у студентів $(n=55)$ з плоскостопістю: $\square$ - ліва кінцівка; $\square$ - права кінцівка 
варіабельним. Тобто цей параметр має великий розкид значень. Результати аналізу нормалізованої швидкості пересування наведені в таблиці 2.

До лікування нормалізована швидкість студентів у середньому була 0,68 $\pm 0,43 \mathrm{~m} \cdot \mathrm{c}^{-1}$. Студенти обох груп пересувалися однаково $(p=0,619)$. Через рік після впровадження авторської програми у всіх студентів спостерігалося значне збільшення нормалізованої швидкості в середньому до до $1,2 \pm 0,24 \mathrm{~m} \cdot \mathrm{c}^{-1}$. Знову між групами не було значущої різниці $(p=0,737)$.

Через два роки відмічали значне збільшення швидкості пересування $\left(2,0 \pm 0,22 \mathrm{~m} \cdot \mathrm{c}^{-1}\right)$ однаково в обох групах ( $p=0,857)$. Причому в обох групах зниження нормалізованої швидкості на другий рік спостереження після впровадження авторської програми було статистично значущим $(p=0,001)$.

Збільшення нормалізованої швидкості відбулося в середньому на $1,2 \mathrm{~m} \cdot \mathrm{c}^{-1}$.

Аналіз якості ходьби проводили за протоколом FAP (Functional Ambulation Perfomance Score). Статистичний аналіз показав, що до впровадження авторської програми майже $75 \%$ студентів користувалися пронаторами чи супінаторами. При цьому 15 студентів не змогли подолати доріжку SIGMA XL повністю під темп, заданий метроном.

Через рік після впровадження авторської програми понад 60 \% студентів пересувалися без пронаторів чи супінаторів. Пронаторами користувалися 32,5 \% студентів. У віддаленому періоді спостереження (через два роки) ними користувалися тільки 20,5 \% студентів. Статистичний аналіз виявив значущу різницю між цими термінами спостереження (табл. 3).

Якщо за результатами аналізу було доведено, що до початку лікування не було виявлено значної різниці в оцінці ходьби студентів ( $\mathrm{t}=-0,572 ; \mathrm{p}=0,570)$, то через рік на контрольному огляді було визначено, що якість ходьби студентів ОГ (71,3 \pm 3,61 бала) статистично значущо ( $t=2,333 ; p=0,024)$ була кращою, ніж у студентів КГ (68,2 \pm 6,54 бала).

Через два роки після впровадження авторської програми спостерігалося збільшення середнього бала FAP в обох групах студентів, але бал за FAP у студентів ОГ був статистично значущо більшим ( $\mathrm{t}=2,559 ; \mathrm{p}=0,014)$, ніж бал за FAP у студентів КГ - 75,6 $\pm 4,44$. Але, незважаючи на те що у студентів КГ залишалося помітне зменшення якості ходьби, ця зміна не досягла значущого рівня ( $t=0,395 ; p=0,697)$.

Дискусія. За результатами статистичного дослідження параметрів ходьби студентів 3
ТАБЛИЦЯ 2 - Результати статистичного аналізу даних «нормалізована швидкість» та порівняння груп студентів упродовж спостереження

\begin{tabular}{|l|l|c|}
\hline \multicolumn{1}{|c|}{$\begin{array}{c}\text { Термін } \\
\text { спостереження }\end{array}$} & \multicolumn{1}{|c|}{$\begin{array}{c}\text { Статистичний } \\
\text { показник }\end{array}$} & Результат \\
\hline \multirow{2}{*}{ До лікування } & $\mathrm{M} \pm \mathrm{SD}$ & $0,67 \pm 0,43$ \\
\cline { 2 - 3 } & $\begin{array}{l}\text { T-тест для незалежних } \\
\text { вибірок (t, p) }\end{array}$ & $\mathrm{t}=0,501 ; \mathrm{p}=0,619$ \\
\hline \multirow{2}{*}{ рік } & $\mathrm{M} \pm \mathrm{SD}$ & $1,2 \pm 0,24$ \\
\cline { 2 - 3 } & $\begin{array}{l}\text { T-тест для незалежних } \\
\text { вибірок (t, p) }\end{array}$ & $\mathrm{t}=-0,338 ; \mathrm{p}=0,737$ \\
\hline \multirow{2}{*}{ роки } & М \pm SD & $2,0 \pm 0,22$ \\
\cline { 2 - 3 } & $\begin{array}{l}\text { Т-тест для незалежних } \\
\text { вибірок (t, p) }\end{array}$ & $\mathrm{t}=-0,182 ; \mathrm{p}=0,857$ \\
\hline
\end{tabular}

Примітка. У таблицях 2 і 3 - t - критерій Вілкоксона; р - статистична значущість розходжень за критерієм Манна-Уїтні.

ТАБЛИЦЯ 3 - Динаміка показників FAP у студентів на плоскостопість (ОГ) і плоскостопість, поєднану з порушеннями постави (КГ)

\begin{tabular}{|c|c|c|c|}
\hline $\begin{array}{c}\text { Термін } \\
\text { спостереження }\end{array}$ & $\begin{array}{l}\text { Статистичний } \\
\text { показник }\end{array}$ & ОГ $(n=60)$ & КГ $(n=60)$ \\
\hline \multirow[t]{2}{*}{ До лікування } & $M \pm S D$ & $50,5 \pm 7,73$ & $49,2 \pm 8,12$ \\
\hline & $\begin{array}{l}\text { Т-тест для незалеж- } \\
\text { них вибірок (t, p) }\end{array}$ & \multicolumn{2}{|c|}{$\mathrm{t}=-0,572 ; \mathrm{p}=0,570$} \\
\hline \multirow[t]{2}{*}{1 рік } & $\mathrm{M} \pm \mathrm{SD}$ & $71,3 \pm 3,61$ & $68,2 \pm 6,54$ \\
\hline & $\begin{array}{l}\text { Т-тест для незалеж- } \\
\text { них вибірок (t, p) }\end{array}$ & \multicolumn{2}{|c|}{$t=2,333 ; p=0,024$} \\
\hline \multirow[t]{2}{*}{2 роки } & $\mathrm{M} \pm \mathrm{SD}$ & $79,7 \pm 4,69$ & $75,6 \pm 4,44$ \\
\hline & $\begin{array}{l}\text { Т-тест для незалеж- } \\
\text { них вибірок }(t, p)\end{array}$ & \multicolumn{2}{|c|}{$t=2,559 ; p=0,014$} \\
\hline
\end{tabular}

плоскостопістю (від першого звернення до двох років після впровадження авторської програми), було визначено деякі закономірності для студентів, у яких електроміографрічно було виявлено зменшення дисбалансу тонусу м'язів різних МФКЛ (переважно група студентів з монопатологією), та для студентів, у яких дисбаланс залишився без зміни (24,7 \% студентів з комплексною патологією). На можливість використання даних про дисбаланс м'язів у різних МФКЛ вказують інші автори $[6,8,14]$.

Отже, до впровадження авторської програми групи за параметрами ходьби були однаковими, тобто у студентів простежувалися всі ознаки спотворення ходьби внаслідок сколіотичної постави під час первинного ураженні САС. Таке комплексне ураження опопрно-рухового апарату $є$ небезпечним з огляду на можливі ускладнення [2, 11]. Це проявлялося у збільшенні тривалості опори на контрлатеральну кінцівку з боку сколіотичного вигину хребта i, відповідно, у зменшенні довжини кроків обох кінцівок [4]. При намаганні збільшити швидкість пересування студенти підвищували тривалість опори на стопу, але довжина 
кроку контрлатеральної кінцівки при цьому майже не збільшувалася. Це, на думку С. С. Страфрун і співавт., [16], може призвести до зростання асиметрії навантаження на кожну стопу та асиметрії довжини кроків. Така асиметрія є біомеханічною підставою для розвитку та подальшого зростання сколіотичного вигину хребта [5] і порушення рівноваги [18].

Впровадження авторської програми у більшості студентів призводило до відновлення параметрів ходьби, хоча здебільшого їх нормалізація не досягала середньостатистичної референтної норми, але практично відновлювала якість ходьби. На позитивний вплив аквафрітнесу на ці параметри вказуть також інші автори [7, 11].

При плоскостопості у студентів змінюється характер постановки стопи, а саме виникає іï розворот латерально, і у 36,7 \% випадків через розвиток контрактур приведення-відведення. За таких умов відмічається зміщення анатомічного центру ваги нижньої кінцівки у латеральний бік $[13,17]$.

Після впровадження авторської програми ці вади в більшості студентів було виправлено, хоча і недостатньо, через малу тривалість програми. Тобто через два роки після впровадження авторської програми, на момент, коли студенти вже повністю освоїли фрізичні вправи і засоби фрізичної терапії, спостерігалося значне покращання параметрів ходьби.

Як відомо, якість ходьби обумовлює не тільки стан м'язової системи спини, поперекового відділу хребта та всієї нижньої кінцівки, а й постійність виконання рекомендацій і тривалість процесу фрізичної терапії [16].

Результати нашого дослідження добре узгоджуються $з$ даними інших авторів. Як показали Р. І. Крамцова і співав., [5], В. П. Лукьяненко і співавт., [8] і С. С. Страфрун і співавт., [16], при зменшенні тонусу м'язів і, особливо, при їх дисбалансі, хворому треба прикладати більше зусиль для здійснення рухів, а саме ходьби. Таким чином, у студентів зі зменшеною функціональною здатністю скелетних м'язів відбувалося постійне перенапруження досліджуваних м'язів, що у віддаленому періоді могло призвести до розвитку чи прогресування дегенеративних змін у надп'ятково-гомілковому суглобі, колінному та поперековому відділах хребта [2, 6, 12]. Треба наголосити, що впровадження авторської програми проводили у студентів 17-19 років, у більшості з яких тривалість захворювання становить не менше 5-8 років. I те, що у більшості з них через два роки застосування засобів фрізичної терапії за протоколом запропонованої авторської програми не виявили набутих інших, додаткових захворювань ОРА, $\epsilon$ показником ефективності такої програми [7, 11]. Це стало можливим за рахунок нівелювання після занять у басейні 3 теплою водою додаткового постійного асиметричного напруження м'язів нижніх кінцівок, що, на думку D.A. Marinho et al., [21], не дозволило збільшити швидкість прогресування дегенеративних змін у суглобах. На це вказують показники електронейроміографрічного дослідження та показники якості ходьби, отримані після закінчення авторської програми. На широкі можливості використання ЕНМГ-дослідження за таких умов вказують Л. Ф. Васильева та Ю. В. Шишмаков [2].

Отже, враховуючи можливість постійного прогресування цього захворювання, ми рекомендували студентам продовжувати застосовувати елементи програми фрізичної терапії якомога довше, що співпадає з даними О. Г. Сафоничевої та співавт. [14].

\section{Висновки}

1. Зменшення тонусу і дисбаланс м'язів гомілки і спини є об'єктивною причиною втрати навичок якісної ходьби, що студенти показували до впровадження авторської програми. Тобто тривале несиметричне навантаження м'язів призводить до втрати оптимальних показників ходьби, зменшення опорної спроможності стопи, що виражається збільшенням часу опори на стопу із порушенням склепінчастого апарату стопи і збільшенням тривалості кроку. Наслідком цих змін $€$ розвиток та поступове прогресування сколіотичної хвороби.

2. Застосування у програми фрізичної терапії студентів з плоскостопістю і фрункціональними порушеннями постави модифікованих ігрових видів фрізичних вправ у воді сприяє підвищенню частотно-амплітудних характеристик м'язів окремих міофасціальних кінематичних ланцюгів і зменшенню дисбалансу між ними, сприяє покращенню показників, що характеризують якість ходьби.

Перспективи подальших досліджень полягають у вивченні впливу методів фрізичної терапії на електроміографрічні параметри м'язів різних міофасціальних кінематичних ланцюгів та параметри якості ходьби з метою обґрунтування доцільності їх використання як ефективних засобів лікування та профрілактики захворювань опорнорухового апарату у людей різного віку.

Конфлікт інтересів. Автори заявляють про відсутність конфлікту інтересів при підготовці даної статті. 


\section{Література}

1. Болобан ВН, Мистулова ТЕ. Стабилография: достижения и перспективы [Stabilography: achievements and prospects]. Наука в олимпийском спорте. Спец. выпуск. 2000: 5-13.

2. Васильева ЛФ, Шишмаков ЮВ. Возможности ЭМГдиагностики в объективизации мануального мышечного теста [Possibilities of EMG diagnostics in objectivisation of manual muscle test]. Мануальная терапия. 2009;35(3): 73-80.

3. Ганузин ВМ. Динамика показателей патологии опорнодвигательного аппарата у детей за период с 1998 по 2013 год [Dynamics of indices of pathology of the musculoskeletal system in children for the period from 1998 to 2013]. Вопросы школьной и университетской медицины и здоровья. 2014;3: 35-36.

4. Йлтухівський МВ, Величко ТО. Просторово-часові параметри ходи в юнаків [Spatial-temporal parameters of young men walking\}. Вісник морфології. 2009;15(2): 449-453.

5. Крамцов PI, Курганский АМ. Функциональная устойчивость вертикальной позы у детей в зависимости от состояния свода стопы [The functional stability of the vertical posture in children depending on the state of the arch of the foot]. Becmник российской академии медицинских наук. 2009;5: 41-43.

6. Кузнецов ОВ. Болевые мышечные синдромы как клиническая манифестация патобиомеханики мышечно-фасциальных цепей [Spatial-temporal parameters of young men walking]. Мануальная терапия. 2009;35(3): 12-19.

7. Ловейко ИД. Лечебная фризическая культура при дефектах осанки, сколиозах и плоскостопии [Therapeutic physical education for defects in posture, scoliosis and flat feet]. Ленинград: Медицина; 1982. 166 с.

8. Лукьяненко ВП, Петрякова ВГ. Влияние гипотонии мышц голени и стопы на формирование плоскостопия у детей дошкольного возраста [Effect of hypotonia of the muscles of the leg and foot on the formation of flat-footedness in children of preschool age]. Адаптивная фризическая культура. 2011;48(4): 27-29.

9. Мацейко II, Тиднюк ДВ, Бекас ВА. Про вивчення теорії міофасциальних ланцюгів при підготовці фрізичних терапевтів [About studying a theory of myofascial chains during preparation of physical therapists]. Фізична культура, спорт та здоров'я нації. 2018;5: 397-403.

10. Московко ГС. Дослідження функції ходи за допомогою SIGMAXL: описання та нормативні дані [Upcoming functions of walking by means of SIGMA XL: description and regulatory data]. Biomedical and Biosocial Anthropology. 2007;8: 18-22.

11. Пенькова ИВ. Новые подходы к профилактике нарушений осанки и сводов стоп у детей на занятиях по фи- зическому воспитанию [New approaches to the prevention of disorders of posture and arches of the feet in children in physical education classes]. Дошкольное воспитание. 2010;9: 118123.

12. Пешкова ОВ, Мятыга ЕН, Бисмак ЕВ. Физическая реабилитация при нарушениях осанки и плоскостопии [Physical rehabilitation for violations of posture and flat feet]. Харьков: СПДФЛ; 2012. 126 с.

13. Попель СЛ, Мицкан БМ, Гевкалюк НО. Спортивна морфологія [Sports morphology]. Івано-Франківськ: ІМЦ; 2009. $120 \mathrm{c}$

14. Сафоничева ОГ, Наминов ВЛ, Хадиков ВИ. Комплексное лечение миофасциальных болевых и мышечнокомпрессионных шейно-плечевых синдромов в условиях санатория [Comprehensive treatment of myofascial pain and muscle compression of the cervico-shoulder syndromes in a sanatorium]. Мануальная терапия. 2009;34(2): 59-64.

15. Стельмащук ПО, Щипіцина ОВ, Башинський OІ. Основні аспекти спіралевидного розташування скелетних м'язів [Basic aspects of spiral skeletal muscle placement]. Bicник Вінницького національного медичного університету. 2008;12(1): 162-167.

16. Страфун СС, Фіщенко ОВ, Карпінська ОД. Біомеханічні особливості ходьби студентів на плоскостопість за даними системи SIGMA XL. Частина 1. Геометричні параметри ходьби [Biomechanical features of students walking on flat feet according to SIGMA XL. Part 1. Geometric parameters of walking]. Травма. 2018;1(19): 7-14.

17. Федонюк ЯІ, Мицкан БМ, Попель Сл. Функціональна анатомія [Functional anatomy]. Тернопіль: Навчальна книга; 2008. $552 \mathrm{c}$

18. Финченко СН. Взаимосвязь деформации стоп и чувства равновесия у женщин [Relationship between foot deformity and feelings of balance in women]. Современные проблемы науки и образования. 2012;4: 1-12.

19. Шеромова НН, Осипова АН. Влияние односторонних нарушений осанки на продольные размеры стопы человека [The effect of unilateral posture disorders on the long dimensions of the human foot]. Новая наука: Cтратегии и векторы развития. 2015;2: 3-7.

20. Gouelle A. Use of Functional Ambulation Performance Score as measurement of gait ability. Journal of Rehabilitation Research \& Development. 2014;51(5): 665-674.

21. Marinho DA, Fahl LB, Neiva HP. The effects of water exercise on physical fitness and health parameters. CPQ Orthopaedics. 2019;3:1-3. 